\title{
Population ecology of the barnacle Chthamalus stellatus in the northwest Mediterranean
}

\author{
L. Benedetti-Cecchi*, S. Acunto, F. Bulleri, F. Cinelli
}

Dipartimento di Scienze dell'Uomo e dell'Ambiente, via A. Volta 6, 56126 Pisa, Italy

\begin{abstract}
This study examined patterns in the distribution and demography of the barnacle Chthamalus stellatus (Poli) at different spatial scales in the northwest Mediterranean. Preliminary data indicated that the abundance and size of barnacles decreased from high-shore to low-shore habitats. The generality of these patterns was investigated at several locations (10s to $100 \mathrm{~s}$ of $\mathrm{km}$ apart), at several sites within locations (100s to $1000 \mathrm{~s}$ of $\mathrm{m}$ apart) and at different times. Patterns were consistent with the preliminary observations, despite considerable spatial and temporal variability at small and large spatial scales. The following models were proposed to explain the observed patterns: (1) recruitment was intrinsically greater high on the shore, (2) limitation of recruitment due to pre-emption of the substratum was greater low than high on the shore, (3) environmental conditions reduce growth low on the shore, and (4) mortality was greater low on the shore. The predictions of these models were tested by examining patterns of recruitment, growth and mortality of barnacles and availability of free space in relation to height on the shore, at several spatial scales and through time. Successful recruitment of barnacles was observed at different heights on the shore where resident organisms were removed, despite a trend toward a larger number of recruits high on the shore at 1 location (Livorno). Availability of bare rock for recruitment was greater high on the shore, implying that pre-emption of the substratum was more intense low on the shore. There was no evidence to suggest that barnacles grew faster on the high shore than on the low shore. The opposite pattern was observed for young barnacles in several cases. Mortality rates were generally greater in low-shore than high-shore habitats for young and for adult barnacles. Patterns emerged over a background of considerable spatial and temporal variation. These results emphasized the importance of pre-emption of space and mortality of juveniles in generating patterns in the distribution and structure of populations of barnacles on rocky shores in the northwest Mediterranean.
\end{abstract}

KEY WORDS: Barnacles - Chthamalus stellatus - Demography · Multiscale analyses - Spatial variation - Temporal variation

\section{INTRODUCTION}

As an ultimate goal ecology should provide explanations for the variability observed in the distribution and abundance of natural populations. Understanding causal processes initially relies on appropriate description of pattern. Manipulative experiments are then necessary to identify the mechanisms underlying the observed patterns. Patterns in assemblages are generated by physical and biological processes influencing the recruitment, growth and mortality of organisms at a variety of spatial and temporal scales. There-

•E-mail: bencecc@discat.unipi.it fore, investigating the magnitude, scales and causes of demographic variation is central to the development of ecological theory. The importance of scale in the analysis of pattern has recently received considerable attention (Levin 1992, Schneider 1994), and scales of variation in the distribution and abundance of populations have been documented both in terrestrial and aquatic systems (Carlile et al. 1989, Rossi et al. 1992, Thrush et al. 1994, Underwood \& Chapman 1996).

Barnacles are convenient organisms to address these issues. They are abundant and common on rocky shores throughout the world (Stephenson \& Stephenson 1949), their biology and life histories are well known (Southward 1987), and they have been used as test organisms to investigate ecological models related 
to competition and predation (Connell 1961a,b); dispersal and recruitment (Grosberg 1982, Caffey 1985, Gaines \& Roughgarden 1985, Roughgarden et al. 1987, Raimondi 1990), and demographic models for species with complex life cycles (Roughgarden et al. 1985, 1988). More recently, studies have investigated the roles of water flow, supply of food and availability of free space on the dynamics and structure of populations of intertidal barnacles (Gaines \& Roughgarden 1985, Roughgarden et al. 1985, Bertness et al. 1991, Minchinton \& Scheibling 1993, Sanford et al. 1994). Although some of these studies have included analyses of scales of variability in patterns of distribution and abundance, multiscale analyses of demographic variables are uncommon (but see Bertness et al. 1991, Hyder et al. 1998).

The barnacle Chthamalus stellatus (Poli) is the most common sessile invertebrate in midlittoral rocky shore assemblages of the northwest Mediterranean. These organisms may occur at various heights on the shore but, on average, are more abundant in high-shore habitats ( 0.4 to $0.7 \mathrm{~m}$ above Mean Low Water Level, MLWL), despite considerable variation in density of barnacles among sites (Benedetti-Cecchi et al. 1999, Menconi et al. 1999). Previous experimental studies have shown that the recruitment of barnacles low on the shore may be limited by the availability of free space and by interactions with macroalgae (BenedettiCecchi et al. 1999, Benedetti-Cecchi 2000). There is also a tendency for low shore barnacles to be smaller and have a lower reproductive output than individuals higher on the shore (Benedetti-Cecchi \& Acunto unpubl. data). These patterns, however, have been documented at a limited number of sites and are not indicative of any general regional pattern.

Here, we have investigated scales of variability in the distribution and demography of Chthamalus stellatus at a number of locations in the northwest Mediterranean. C. montagui was not considered because it was uncommon on the shores examined, although rocky shores in the northern part of the Ligurian Sea and the Adriatic can support dense populations of this species (Pannacciulli et al. unpubl. data). First, we tested whether the preliminary observations that barnacles higher on the shore were more abundant and larger than those occurring lower down were consistent at different spatial scales and through time. Then we tested the predictions of a number of models that could explain the observed patterns: (1) barnacles are more abundant high on the shore because recruitment is intrinsically greater there than low on the shore (perhaps due to physical transportation of larvae), (2) barnacles are more abundant high on the shore because recruitment is prevented by pre-emption of the substratum in low-shore habitats, (3) barnacles are smaller low on the shore because environmental conditions reduce growth in comparison to high-shore habitats (perhaps due to interactions with other organisms), and (4) barnacles are smaller low on the shore because environmental factors increase mortality so that they have a smaller probability of growing to adult stages than do those occurring higher up on the shore. The first model predicts that if patches of bare rock are cleared at different heights on the shore (to reduce the effects of resident organisms), then recruitment will be greater in high-shore than low-shore habitats. The second model predicts that bare rock available for recruitment will be greater low on the shore rather than higher up. The third model predicts that growth of barnacles will be faster high on the shore, while the fourth model predicts faster rates of mortality low on the shore. Clearly, these models are not mutually exclusive and the observed patterns in abundance and size of barnacles may result from any possible combination of the proposed explanations.

To discriminate among the alternative explanations, we examined patterns of recruitment of barnacles in experimental plots cleared at different heights on the shore, in different places and at different times. In addition, annual growth and mortality were examined for 2 consecutive years at different spatial scales, ranging from patches a few metres apart to locations hundreds of kilometres apart.

\section{MATERIALS AND METHODS}

Study system. This study was done at 4 localities in the northwest Mediterranean, 10s to $100 \mathrm{~s}$ of $\mathrm{km}$ apart (Fig. 1). These localities supported similar assemblages of algae and invertebrates, although the relative abundance of some organisms and their specific patterns of distribution differ among localities (Menconi et al. 1999, Benedetti-Cecchi et al. unpubl. data). Barnacles were the most common sessile invertebrates in midand high-shore habitats. The upper limit of Chthamalus stellatus was between 30 and $40 \mathrm{~cm}$ above the upper limit of the tides at our study sites. At mid heights, barnacles were mixed with macroalgae, particularly the fleshy red alga Rissoella verruculosa (Bertolini) J. Agardh, filamentous green and red algae, the encrusting brown Ralfsia verrucosa (Areschough) J. Agardh and cyanobacteria (genera Calothrix and Rivularia). Low on the shore, encrusting coralline algae were common and barnacles more sparse. Limpets Patella aspera Roeding and P. rustica L. are the most important grazers on these shores while carnivores, such as the whelk Thais haemastoma (L.) and the sea star Coscinasterias tenuispina (Lamark), were occasionally present at some localities. 
Patterns in size and abundance of barnacles and availability of bare rock. To test the hypothesis that barnacles high on the shore were consistently larger than those lower down (as initially observed at Livorno; Benedetti-Cecchi \& Acunto unpubl. data), we compared the size of barnacles at 2 heights on the shore at a hierarchy of spatial scales in the northwest Mediterranean. The sampling design included 3 locations $100 \mathrm{~s}$ of km apart (Baratti, Capraia and Livorno, Fig. 1), 3 sites within each location (100s to $1000 \mathrm{~s} \mathrm{~m}$ apart) and 3 patches within each site ( 3 to $10 \mathrm{~m}$ apart). A site was a stretch of coastline 30 to $50 \mathrm{~m}$ in length, while patches were 2 to $3 \mathrm{~m}$ in length. In July-August 1996, 6 replicate plots $(7 \times 5 \mathrm{~cm})$ were photographed at high $(40$ to $50 \mathrm{~cm}$ above MLWL) and low (10 to $20 \mathrm{~cm}$ above MLWL) heights in each patch, using a Nikonos $\mathrm{V}$ camera with an electronic flash and an extension tube for macro photography ( $1: 2$ reproduction ratio with a $35 \mathrm{~mm}$ lens). The same sites were used for the analysis of patterns of growth and mortality of barnacles described below (see 'Growth and mortality'). Five barnacles were selected randomly in each slide and their size recorded as the opercular diameter measured under a dissecting microscope with a micrometric eye piece (to the nearest $0.01 \mathrm{~mm}$ ).

The distribution of barnacles and the availability of bare rock were examined at 2 localities (Capraia and Livorno, Fig. 1). Each location was sampled twice between January and May 1998. For each date, 6 sites (stretches of shore of 10 to $15 \mathrm{~m}$ ) were selected randomly along 4 to $5 \mathrm{~km}$ of rocky coast at each location. Two patches (stretches of shore of 1.5 to $2 \mathrm{~m}$ ) were selected randomly at each site and the percentage cover of barnacles and bare rock was assessed at 4 heights in each patch, by sampling 3 replicate quadrats of $15 \times 10 \mathrm{~cm}$ at each height. Heights were at levels on the shore 30 , 20,10 and $0 \mathrm{~cm}$ above the MLWL, as determined from tide-tables. These heights matched macroscopic changes in the structure of assemblages along the vertical gradient. Percentage cover values were determined using a plastic frame divided into 25 sub-quadrats of $3 \times 2 \mathrm{~cm}$ each, and after visual inspection a score from 0 to $4 \%$ was given to each taxon in each sub-quadrat. Final cover was obtained by summing over the 25 small quadrats (Dethier et al. 1993, BenedettiCecchi et al. 1996).
Data on barnacle size were analysed using a 5 -factor mixed model ANOVA with the following factors: Location (random and orthogonal), Site (random, nested within Location), Patch (random, nested within Site), Height (fixed and orthogonal) and Plot (random and nested within the interaction between Height and Patch). A 5-factor mixed model ANOVA was also used to analyse patterns of abundance of barnacles and availability of bare rock. Factors were: Location (random and orthogonal), Date (random and nested within Location), Site (random and nested within Date), Patch (random and nested within Site), and Height (fixed and

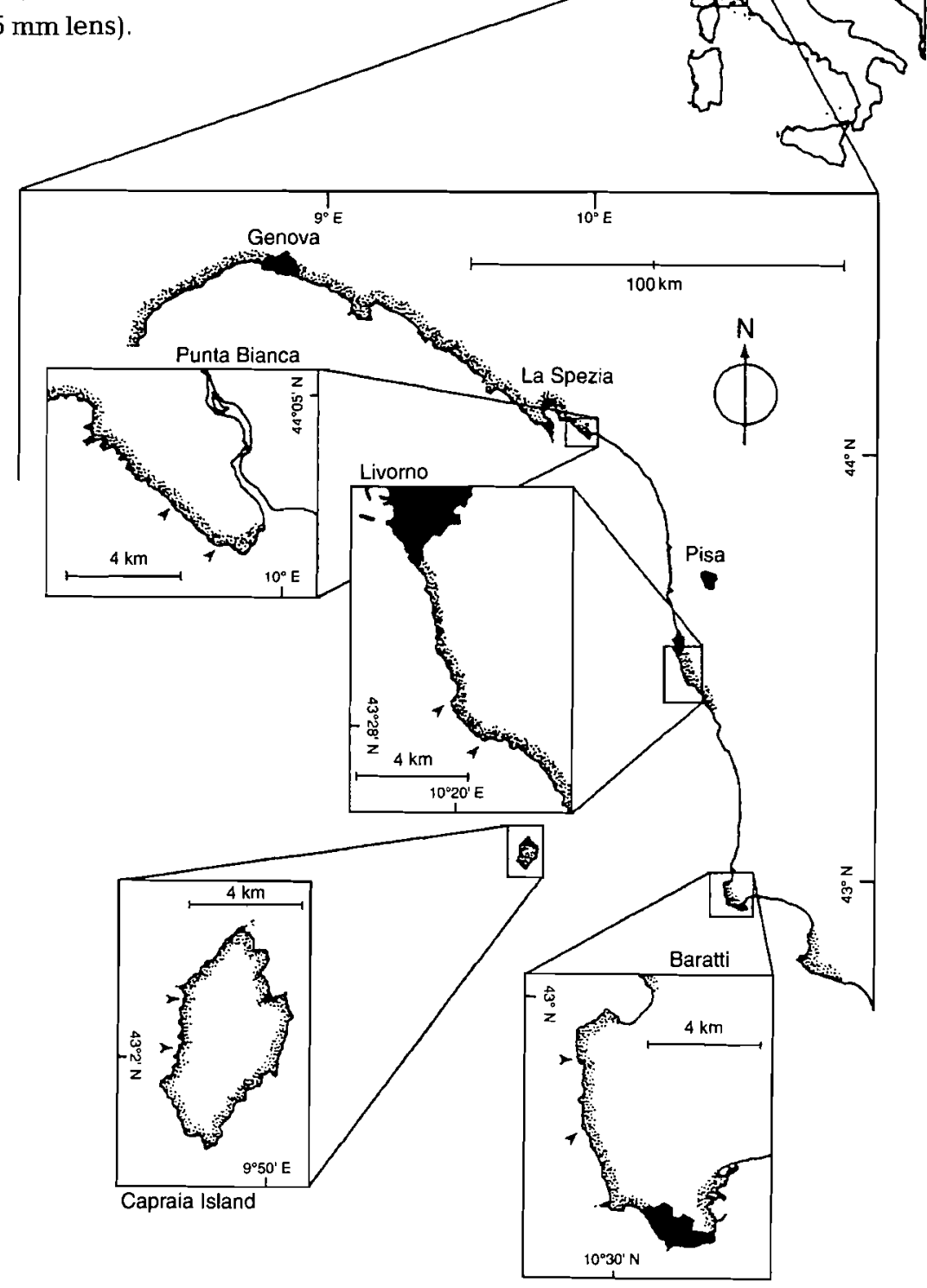

Fig. 1. Map of the study area in the northwest Mediterranean 
orthogonal). In this and the subsequent analyses, Cochran's $C$-test was used to examine the assumption of homogeneity of variances. If necessary, data were log-transformed to eliminate or reduce heterogeneity of variances. Student-Neuman-Keuls (SNK) tests were used for multiple comparisons of the means (at $\alpha=$ 0.05). Anderson's test (Winer et al. 1991) was used to test for the significance of differences in the frequency at which treatments were given a particular rank by SNK tests in a series of multiple comparisons.

Patterns of recruitment. Patterns of recruitment were examined in plots of $10 \times 15 \mathrm{~cm}$ scraped clean of resident organisms at Livorno and Punta Bianca (Fig. 1). The experiment was initiated before the main settlement period of barnacles, which occurs in JulyAugust at these locations (Benedetti-Cecchi \& Acunto unpubl. data). A first set of plots was cleared in January 1998 and a second set was cleared in June 1998 at each location. In this way, plots of different age with a different degree of free space (Benedetti-Cecchi \& Bertocci unpubl. data) were available for barnacles to settle, allowing us to test whether recruitment is affected by the history of the plot (i.e. the total effect of availability of free space and composition of resident assemblages, both in and surrounding the cleared plots). For each date at each location, 2 replicate patches (stretches of shore 3 to $4 \mathrm{~m}$ in length) were selected randomly at each of 4 heights on the shore. Three replicate quadrats in each patch were scraped clean using a hammer and chisel, and marked at their corners with epoxy putty (Subcoat S, Veneziani) for relocation. The 4 heights chosen were: (1) above the upper limit of distribution of Rissoella verruculosa (35 to $40 \mathrm{~cm}$ above MLWL); (2) at the upper margin of distribution of $R$. verruculosa ( 25 to $30 \mathrm{~cm}$ above MLWL); (3) at the lower margin of distribution of $R$. verruculosa (15 to $20 \mathrm{~cm}$ above MLWL), and (4) below the lower limit of distribution of $R$. verruculosa ( 5 to $10 \mathrm{~cm}$ above MLWL).

Recruitment was monitored in August 1998 at both locations. Plots were photographed using a Nikonos $\mathrm{V}$ camera equipped with electronic flash and an extension tube for macro photography (1:3 reproduction ratio with a $35 \mathrm{~mm}$ lens). Slides were examined under a dissecting microscope and the number of spat counted. Data were analysed using a 4-factor ANOVA with the following treatments: Location (random), Age (fixed and orthogonal to location), Height (fixed and orthogonal to Location and Age) and Patch (random and nested within the Height $\times$ Location $\times$ Age interaction).

To further examine variation in recruitment, estimates of spatial variance at different scales were calculated from the data. In this case, ANOVAs were repeated independently for each age and height on the shore and the mean squares, associated to the effect of
Plot (i.e. residual variation), Patch and Location, calculated. Observed values were then equated to the expected mean squares to obtain estimates of spatial variance at the different scales (see Underwood 1997 on how to derive expected mean squares for any given design).

Growth and mortality. Annual growth and mortality of barnacles were examined at the same hierarchy of spatial scales at which the initial size of barnacles was measured, but in 2 consecutive years (1996-1997 and 1997-1998). Permanent quadrats were established at each of 3 sites at each location (Baratti, Capraia and Livorno). Six patches of substratum were randomly selected and marked with epoxy putty at each site in July-August 1996: To obtain temporally independent estimates of growth and mortality, 3 patches (selected randomly among the 6 available) were used in the first year of the study. The other 3 patches were used in the second year. At the beginning of each period, 5 replicate plots were marked at each of 2 heights on the shore in the appropriate patches. Plots were $7 \times 5 \mathrm{~cm}$ in size and were delimited by 2 holes drilled into the rock that corresponded to the upper corners of the quadrats. Small pieces of epoxy putty were also used to facilitate the identification of quadrats. The 2 heights corresponded to high-shore barnacles $(40$ to $50 \mathrm{~cm}$ above MLWL) and to low-shore barnacles (10 to $20 \mathrm{~cm}$ above MLWL).

Plots were photographed as described above (see 'Patterns in size and abundance of barnacles and availability of bare rock'). The holes drilled into the rock facilitated the positioning of the frame so that the same area was sampled at the beginning of the study and after 1 yr. Growth was measured as the annual increase in opercular diameter for juvenile $k 1.5 \mathrm{~mm}$ opercular diameter) and adult (>2.5 $\mathrm{mm}$ opercular diameter) barnacles. Five barnacles of each size class were selected from each slide from the first time of sampling, and their opercular diameter measured. These barnacles were selected randomly with the proviso that they survived until the next year, when they were measured again. Annual growth was calculated as the difference between final and initial measurements and averaged across the 5 barnacles in each plot. Similarly, 5 barnacles of each size class were tracked over the $1 \mathrm{yr}$ periods to calculate the percentage mortality for each plot. These data were analysed using a 5-factor ANOVA, with the following factors: Time (random), Location (random and orthogonal to Time), Site (random, nested within location but or thogonal to Time), Patch (random and nested within the Time $\times$ Site interaction) and Height (fixed and or thogonal to Time, Location, Site and Patch). Some plots were missing by the end of the 1 yr period. This occurred either because plots could not be relocated, 
or because of proliferation of algae that masked the barnacles present in the plots. Missing values were replaced with mean values calculated from the remaining plots in each particular patch, and the degrees of freedom of the residuals adjusted accordingly (Underwood 1997). Estimates of spatial and temporal variance in growth and mortality were obtained as described above (see 'Patterns of recruitment') for juvenile and adult barnacles.

\section{RESULTS}

\section{Patterns in size and abundance of barnacles and availability of bare rock}

Barnacles were significantly larger high than low on the shore, consistently over the spatial scales examined. Although the magnitude of the differences between heights changed across patches and localities, as indicated by the significant Height $\times$ Patch and Height $\times$ Location interactions (Table 1), SNK tests within these interactions indicated that barnacles high on the shore were always significantly larger than those occurring lower down (27 comparisons within the Height $\times$ Patch interaction and 3 comparisons within the Height $\times$ Location interaction). The average magnitude of these differences was $34.5 \%$ at Baratti, $21.7 \%$ at Capraia and $48 \%$ at Livorno. There was, however, considerable variation in the mean size of barnacles at the scale of $10 \mathrm{~s}$ to $100 \mathrm{~s}$ of $\mathrm{cm}$, irrespective of height on the shore, as indicated by the significant effect of Plot in the analysis (Table 1). An example of these patterns is illustrated for barnacles at Capraia (Fig. 2).

There were inconsistencies in the vertical distribution of barnacles from patch to patch, site to site and between locations. These patterns resulted in significant interactions between Height and each of the 3 spatial scales examined (Table 2). This analysis, how-

Table 1. Chthlamalus stellatus. ANOVA of mean sizes. Significant effects relevant to the interpretation of the results are indicated in bold. L: Location, $\mathrm{H}$ : Height

\begin{tabular}{|c|c|c|c|c|c|}
\hline Source of variation & df & MS & $F$ & $\mathrm{p}$ & Denominator for $F$ \\
\hline $\mathrm{L}$ & 2 & 5.958 & 2.1 & $>0.2$ & Site (L) \\
\hline Site (L) & 6 & 2.906 & 1.3 & $>0.3$ & Patch (Site (L)) \\
\hline Patch (Site (L)) & 18 & 2.247 & 5.4 & $<0.0001$ & Plot (Patch (Site (L))) \\
\hline $\mathrm{H}$ & 1 & 236.262 & 23.1 & $<0.05$ & $\mathrm{H} \times \mathrm{L}$ \\
\hline $\mathrm{H} \times \mathrm{L}$ & 2 & 10.217 & 11.9 & $<0.01$ & $\mathrm{H} \times$ Site $(\mathrm{L})$ \\
\hline $\mathrm{H} \times$ Site $(\mathrm{L})$ & 6 & 0.857 & 0.9 & $>0.5$ & $\mathrm{H} \times$ Patch $($ Site $(\mathrm{L}))$ \\
\hline $\mathrm{H} \times$ Patch $($ Site $(\mathrm{L}))$ & 18 & 0.999 & 2.4 & $<0.002$ & Plot $(\mathrm{H} \times$ Patch $($ Site $(\mathrm{L})))$ \\
\hline Plot $(\mathrm{H} \times$ Patch $($ Site $(\mathrm{L})))$ & 270 & 0.420 & 0.7 & $<0.0001$ & Residual \\
\hline Residual & 1296 & 0.616 & & & \\
\hline Cochran's C-test & \multicolumn{3}{|c|}{$\begin{array}{c}C=0.0165, \mathrm{p}>0.05 \\
\text { None }\end{array}$} & & \\
\hline
\end{tabular}

Table 2. Chthamalus stellatus. ANOVA of mean percentage covers. Significant effects relevant to the interpretation of the results are indicated in bold

\begin{tabular}{|c|c|c|c|c|c|c|c|c|}
\hline \multirow[t]{2}{*}{ Source of variation } & \multirow[t]{2}{*}{$\mathrm{df}$} & \multicolumn{3}{|c|}{ Cover of C. stellatus } & \multicolumn{3}{|c|}{ Bare rock } & \multirow[t]{2}{*}{ Denominator for $F$} \\
\hline & & MS & $F$ & $\mathrm{p}$ & MS & $F$ & $\mathrm{p}$ & \\
\hline $\mathrm{L}$ & 1 & 52.04 & 5.42 & $>0.1$ & 7831.6 & 2.2 & $>0.25$ & Date (L) \\
\hline Date (L) & 2 & 9.60 & 2.41 & $>0.1$ & 3557.1 & 4.1 & $<0.05$ & Site (Date (L)) \\
\hline Site (Date (L)) & 20 & 3.99 & 4.98 & $<0.0002$ & 867.9 & 4.4 & $<0.0005$ & Patch (Site (Date (L))) \\
\hline Patch (Site (Date (L))) & 24 & 0.80 & 2.88 & $<0.0001$ & 197.4 & 1.7 & $<0.05$ & Residual \\
\hline $\mathrm{H}$ & 3 & 198.60 & 7.52 & $>0.05$ & 11791.7 & 50.4 & $<0.005$ & $\mathrm{H} \times \mathrm{L}$ \\
\hline $\mathrm{H} \times \mathrm{L}$ & 3 & 26.41 & 13.45 & $<0.005$ & 234.1 & 0.3 & $>0.8$ & $\mathrm{H} \times$ Date $(\mathrm{L})$ \\
\hline $\mathrm{H} \times$ Date $(\mathrm{L})$ & 6 & 1.96 & 1.88 & $>0.09$ & 820.7 & 1.3 & $>0.25$ & $\mathrm{H} \times$ Site $($ Date $(\mathrm{L}))$ \\
\hline $\mathrm{H} \times$ Site (Date $(\mathrm{L}))$ & 60 & 1.04 & 2.06 & $<0.002$ & 629.8 & 2.8 & $<0.0001$ & $\mathrm{H} \times$ Patch (Site (Date (L))) \\
\hline $\mathrm{H} \times$ Patch (Site (Date (L))) & 72 & 0.51 & 1.82 & $<0.0003$ & 222.9 & 1.96 & $<0.0001$ & Residual \\
\hline Residual & 384 & 0.28 & & & & & & \\
\hline Cochran's $C$-test & \multirow{2}{*}{\multicolumn{3}{|c|}{$\begin{array}{c}C=0.1155, \mathrm{p}<0.01 \\
\operatorname{Ln}(x+1)\end{array}$}} & \multirow{2}{*}{\multicolumn{3}{|c|}{$\begin{array}{c}C=0.0562, \mathrm{p}>0.05 \\
\text { None }\end{array}$}} & & \\
\hline Transformation & & & & & & & & \\
\hline
\end{tabular}




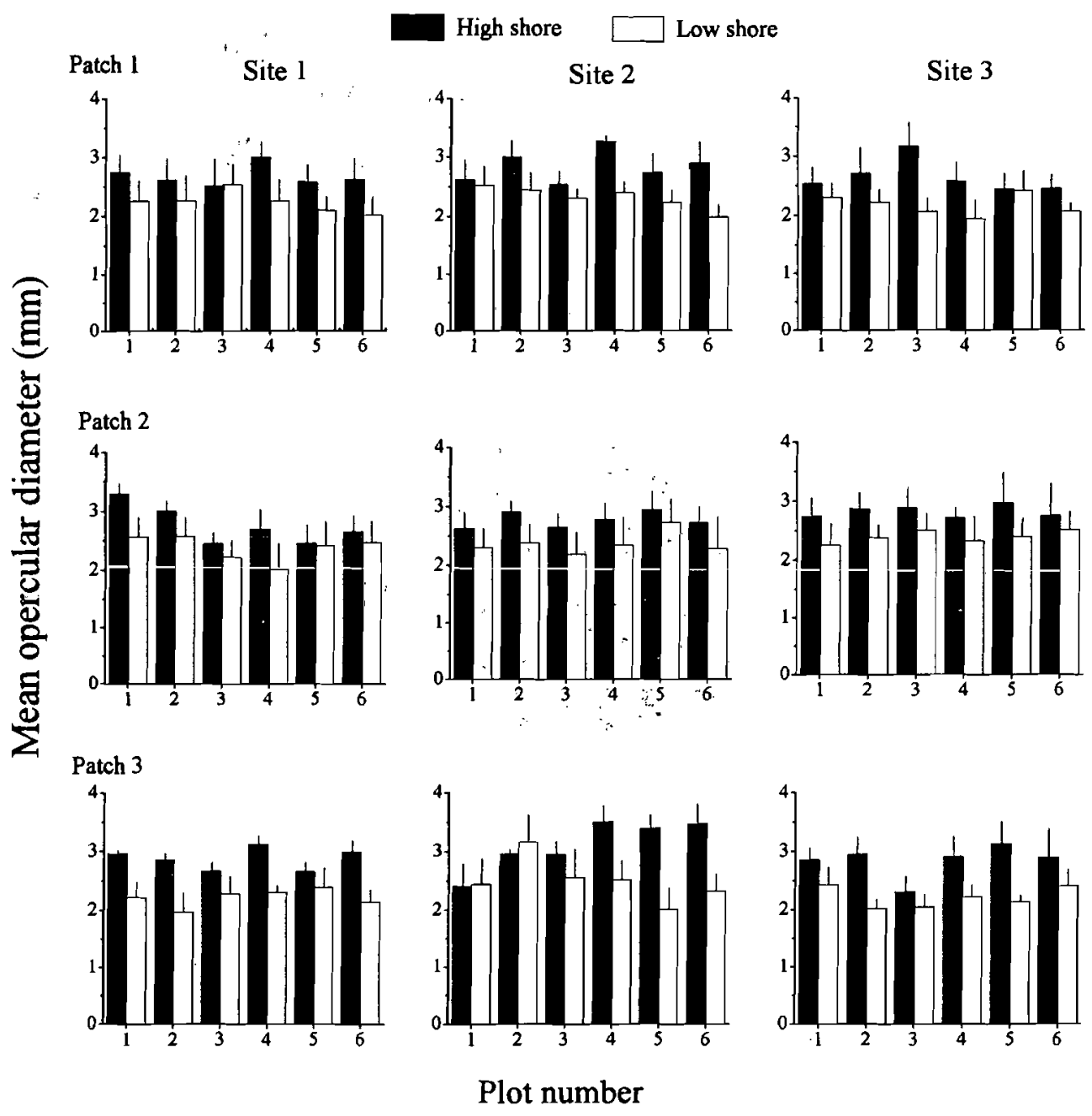

Fig. 2. Chthamalus stellatus. Illustrative example of mean opercular diameter $(+\mathrm{SE}, \mathrm{n}=5$ ) at 3 sites, 3 patches within each site and 2 heights on the shore at Capraia. On average, barnacles high on the shore were $21.7 \%$ larger than those occurring lower down. The magnitude of these differences was $34.5 \%$ at Baratti and $48 \%$ at Livorno (data not shown; see text for details)

ever, must be interpreted cautiously because of heterogeneity of variances. SNK tests within the Height $x$ Patch interaction indicated that barnacles were significantly more abundant $30 \mathrm{~cm}$ above the MLWL than at any other height, consistently across patches (Anderson's test: $Q^{2}=36.8, \mathrm{df}=3, \mathrm{p}<0.001$ ). Thus, the interaction resulted from spatial variation in the magnitude of these differences rather than from changes in the rank order of the heights. An example of these patterns is illustrated for 6 sites sampled on Date 1 at Livorno (Fig. 3). A similar pattern of differences among heights was observed at Livorno on Date 2 and at Capraia.

Bare rock available for recruitment was greater high on the shore rather than lower down both at Livorno and Punta Bianca (Fig. 4). Patterns were, however, variable from patch to patch and site to site as'indicated by the significant Height $\times$ Patch and Height $x$ Site interactions (Table 2). Despite these interactions,
SNK and Anderson's tests indicated that $30 \mathrm{~cm}$ above the MLWL ranked first in the availability of free space significantly more often than any other height (Height $\times$ Patch interaction: $Q^{2}=16.4, \mathrm{p}<0.005$; Height $\times$ Site interaction: $Q^{2}=13.6, \mathrm{p}<0.005$ ).

\section{Patterns of recruitment}

Recruitment was massive at Livorno, while few spat were present in quadrats at Punta Bianca (Fig. 5). The analysis detected a significant Height $\times$ Location interaction (Table 3). SNK tests within this interaction indicated that there was no significant difference among heights at Punta Bianca, and that the only difference occurring at Livorno was that between the 2 most extreme heights considered (i.e. there were more recruits in plots 35 to $40 \mathrm{~cm}$ above the MLWL than in 

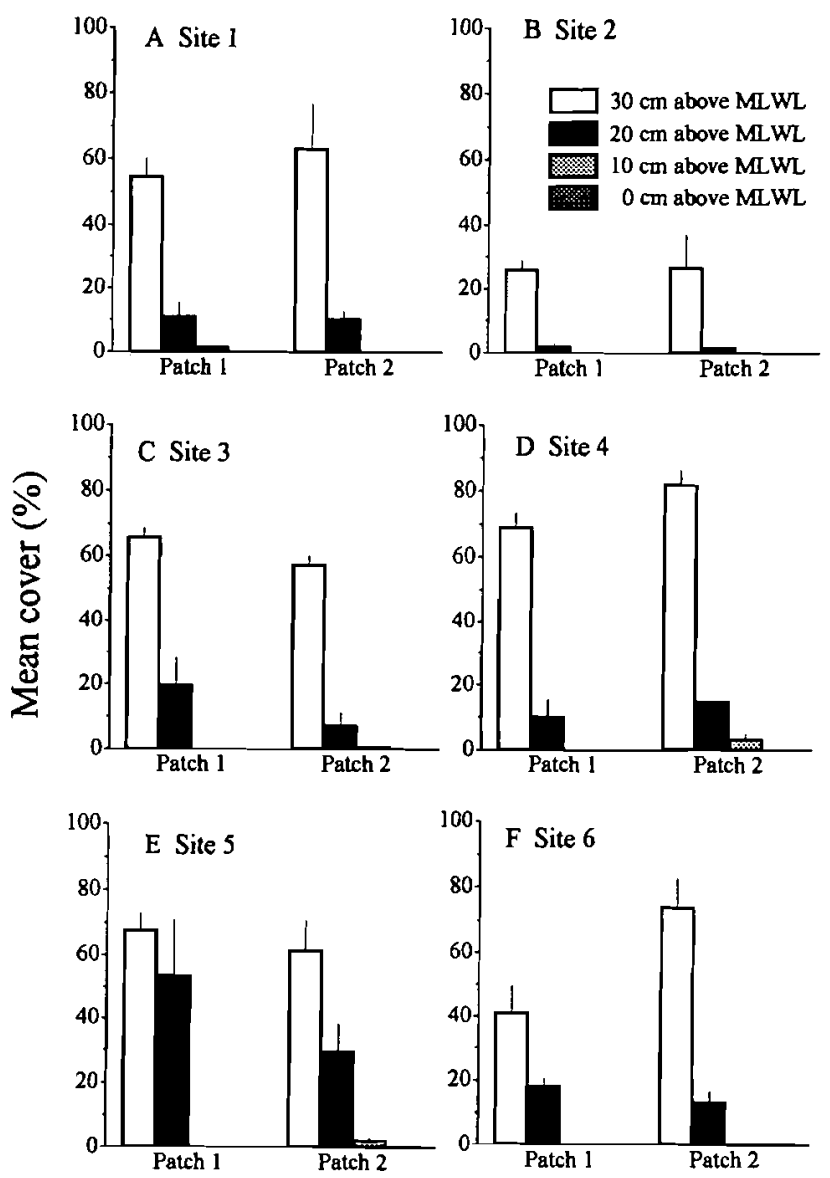

Fig. 3. Chthamalus stellatus. Mean percentage cover (+SE, $\mathrm{n}=3$ ) at different heights on the shore. The example illustrates data from 6 sites at Livorno on Date 1. A similar pattern of differences among heights was observed at Livorno on Date 2 and at Capraia (data not shown; see text for details)

plots 5 to $10 \mathrm{~cm}$ above the MLWL). However, the SNK test could not identify a clear alternative to the null hypothesis of no difference among heights.

Spatial variance in recruitment was very large at the smallest spatial scale (among plots) in lowshore habitats, and decreased with increasing height on the shore (Table 4). The magnitude of variation among plots was comparable to that observed between locations in high-shore habitats (20 and $30 \mathrm{~cm}$ above the MLWL). Variability among patches was negligible (Table 4).

\section{Growth and mortality of barnacles}

There were differences in patterns of growth of juvenile barnacles between high-shore and lowshore habitats. The effect of height was not con- sistent across patches and also interacted with time and location (Table 5). Anderson's test within the Height $\times$ Patch interaction indicated that the mean growth of barnacles living down the shore was ranked highest significantly more often than the mean growth of those occurring high on the shore $\left(Q^{2}=13, \mathrm{df}=1, \mathrm{p}<0.001\right)$. SNK tests within the Height $\times$ Time $\times$ Location interaction indicated that barnacles in low-shore habitats had higher growth rates than those living up on the shore at Capraia in Year 1 (Fig. 6B), and at Livorno in Year 2 (Fig. 6C). In none of these comparisons was there evidence for barnacles living high on the shore growing faster than those living lower down.

Variance in growth of barnacles was largest at the scale of the location and then at the scale of the plot, while variability among patches and sites was negligible (Table 6). Growth was more variable in adult than juvenile barnacles at the scale of the location, both in high-shore and low-shore habitats. Conversely, at the scale of the plot, growth was more variable in juvenile than adult barnacles. There was no temporal variability in patterns of growth of barnacles (Table 6).

Mortality of juvenile barnacles differed between heights, but the differences were not consistent across patches and changed interactively with time and location (Table 7). Nevertheless, Anderson's test within the Height $\times$ Patch interaction indicated that mortality of low-shore barnacles was ranked highest significantly more often than ranks for high-

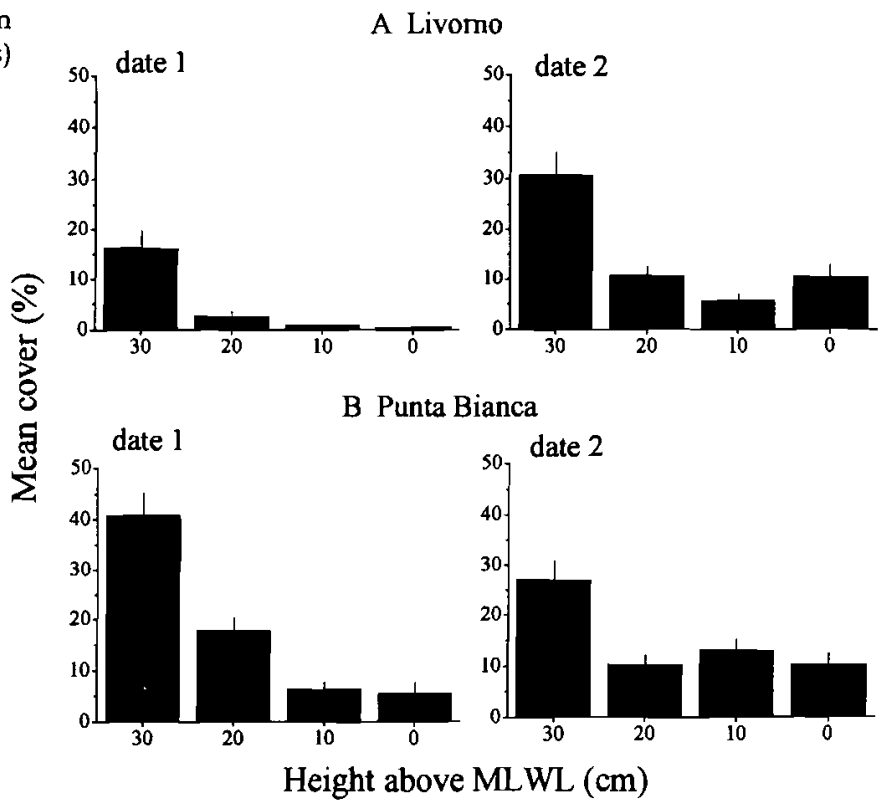

Fig. 4. Bare rock. Mean percentage cover $(+\mathrm{SE}, \mathrm{n}=36$ ) at different heights on the shore. Data are from 3 replicate plots pooled across 2 replicate patches and 6 replicate sites on each date at each location 
Table 3. Chthamalus stellatus. ANOVA of mean densities of recruits. Significant effects relevant to the interpretation of the results are indicated in bold. A: Age

\begin{tabular}{|c|c|c|c|c|c|}
\hline Source of variation & $d f$ & MS & $F$ & $\mathrm{p}$ & Denominator for $F$ \\
\hline $\mathrm{L}$ & 1 & 74.65 & 113.93 & $<0.0001$ & Patch $(\mathrm{H} \times \mathrm{L} \times \mathrm{A})$ \\
\hline A & 1 & 0.71 & 1.97 & $>0.3$ & $A \times L$ \\
\hline $\mathrm{H}$ & 3 & 2.06 & 0.73 & $>0.6$ & $\mathrm{H} \times \mathrm{L}$ \\
\hline$A \times L$ & 1 & 0.36 & 0.55 & $>0.4$ & Patch $(\mathrm{H} \times \mathrm{L} \times \mathrm{A})$ \\
\hline $\mathrm{H} \times \mathrm{L}$ & 3 & 2.84 & 4.34 & $<0.05$ & Patch $(\mathrm{H} \times \mathrm{L} \times \mathrm{A})$ \\
\hline $\mathrm{H} \times \mathrm{A}$ & 3 & 0.58 & 0.42 & $>0.7$ & $\mathrm{H} \times \mathrm{L} \times \mathrm{A}$ \\
\hline $\mathrm{H} \times \mathrm{L} \times \mathrm{A}$ & 3 & 1.38 & 2.11 & $>0.1$ & Patch $(\mathrm{H} \times \mathrm{L} \times \mathrm{A})$ \\
\hline Patch $(H \times L \times A)$ & 16 & 0.65 & 0.51 & $>0.9$ & Residual \\
\hline Residual & 64 & 1.27 & & & \\
\hline Cochran's C-test & \multirow{2}{*}{\multicolumn{5}{|c|}{$\begin{array}{c}C=0.1709, p>0.05 \\
\operatorname{Ln}(x+1)\end{array}$}} \\
\hline Transformation & & & & & \\
\hline
\end{tabular}

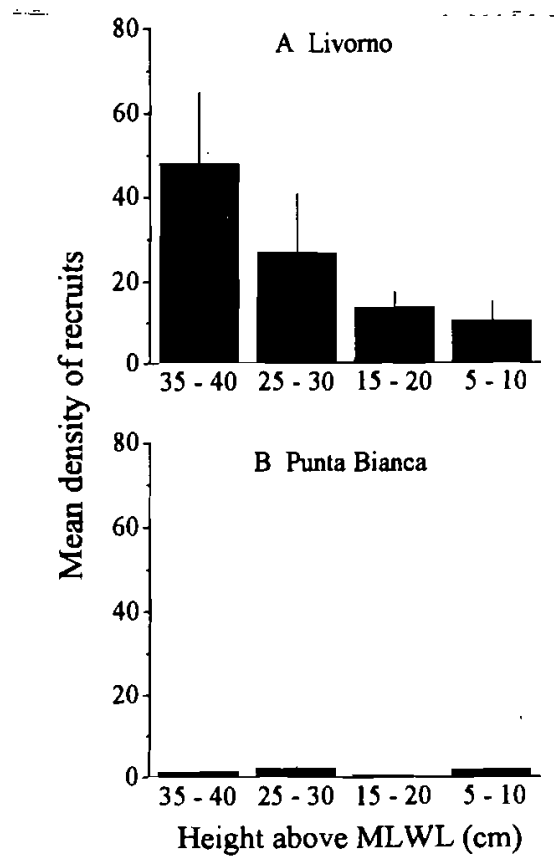

Fig. 5. Chthamalus stellatus. Mean number of recruits ( $+\mathrm{SE}$, $\mathrm{n}=12$ ) at different heights above Mean Low Water Level (MLWL) at 2 localities in the northwest Mediterranean

shore ones $\left(Q^{2}=10.7, \mathrm{df}=1, \mathrm{p}<0.01\right)$. Similarly, SNK tests within the Height $\times$ Time $\times$ Location interaction indicated that mortality was significantly greater in low-shore habitats in all comparisons (Fig. 7). Similar results were obtained for adult barnacles. Mortality in low-shore habitats ranked highest significantly more often than did mortality in high-shore habitats within the Height $\times$ Patch interaction (Anderson's test: $Q^{2}=6$, $\mathrm{df}=1, \mathrm{p}<0.02$ ). An example of this small-scale spatial variability in differences between heights is given for 1 location (Livorno), using data from Year 1 (Fig. 8). SNK tests within the Height $\times$ Time $\times$ Location interac-
Table 4. Estimates of spatial variance in recruitment of barnacles at different scales

\begin{tabular}{|lrrrr|}
\hline $\begin{array}{l}\text { Age } \\
(\mathrm{yr})\end{array}$ & $\begin{array}{c}\text { Height on } \\
\text { the shore }(\mathrm{cm})\end{array}$ & $\sigma_{\text {Plot }}^{2}$ & $\sigma_{\text {Patch }}^{2}$ & $\sigma_{\text {Location }}^{2}$ \\
\hline 1 & 0 & 2319.5 & 107.0 & 648.7 \\
1 & 10 & 2376.0 & 50.3 & 359.0 \\
1 & 20 & 180.1 & 0.0 & 144.0 \\
1 & 30 & 301.1 & 0.0 & 36.3 \\
2 & 0 & 1555.0 & 0.0 & 36.3 \\
2 & 10 & 74.6 & 0.0 & 51.5 \\
2 & 20 & 54.3 & 0.0 & 46.7 \\
2 & 30 & 38.5 & 0.0 & 13.1 \\
\hline
\end{tabular}

tion indicated faster rates of mortality of low-shore barnacles in 4 out of 6 comparisons. In none of these comparisons were rates of mortality of high-shore barnacles significantly larger than those occurring lower down.

Mortality of barnacles was very variable at the scale of the plot, independently of life stage and height on the shore (Table 6). Spatial variance in mortality was also large at the scale of the patch both for juvenile and adult barnacles living in low-shore habitats, and at the scale of the location for juvenile barnacles living low on the shore. There was no temporal variability in patterns of mortality of barnacles, and spatial variability at the scale of the site was negligible (Table 6).

\section{DISCUSSION}

In agreement with the preliminary observations made at Livorno (Benedetti-Cecchi \& Acunto unpubl. data), Chthamalus stellatus was significantly and consistently larger higher up than lower down on the shore in the northwest Mediterranean. Similarly, the cover of this species was greater in high-shore than 
Table 5. Chthamalus stellatus. ANOVA of mean growth of juveniles and adults. Significant effects relevant to the interpretation of the results are indicated in bold. T: Time

\begin{tabular}{|c|c|c|c|c|c|c|c|c|}
\hline \multirow[t]{2}{*}{ Source of variation } & \multirow[t]{2}{*}{ df } & \multicolumn{3}{|c|}{ Juveniles } & \multicolumn{3}{|c|}{ Adults } & \multirow[t]{2}{*}{ Denominator for $F$} \\
\hline & & MS & $F$ & $\mathrm{p}$ & MS & $F$ & $\mathbf{p}$ & \\
\hline $\mathrm{T}$ & 1 & 0.0013 & 0.0 & $>0.9$ & 0.1584 & 0.1 & $>0.8$ & $\mathrm{~T} \times \mathrm{L}$ \\
\hline $\mathrm{L}$ & 2 & 2.7341 & - & - & 1.6454 & - & - & No test \\
\hline Site (L) & 6 & 0.1125 & 1.2 & $>0.4$ & 0.0370 & 0.8 & $>0.5$ & $\mathrm{~T} \times$ Site $(\mathrm{L})$ \\
\hline $\mathrm{T} \times \mathrm{L}$ & 2 & 1.4242 & 14.7 & $<0.005$ & 2.9332 & 65.8 & $<0.0002$ & $\mathrm{~T} \times$ Site $(\mathrm{L})$ \\
\hline $\mathrm{T} \times$ Site $(\mathrm{L})$ & 6 & 0.0971 & 1.2 & $>0.3$ & 0.0446 & 6.9 & $<0.0002$ & Patch $(T \times$ Site $(L))$ \\
\hline Patch $(\mathrm{T} \times$ Site $(\mathrm{L}))$ & 36 & 0.0829 & 5.1 & $<0.0001$ & 0.0065 & 1.5 & $<0.05$ & Residual \\
\hline $\mathrm{H}$ & 1 & 0.9582 & - & - & $0.0551^{\mathrm{c}}$ & 4.1 & $>0.05$ & $\mathrm{H} \times \mathrm{T} \times$ Site $(\mathrm{L})$ \\
\hline $\mathrm{H} \times \mathrm{T}$ & 1 & 0.0281 & 0.2 & $>0.6$ & 0.0127 & 2.4 & $>0.2$ & $\mathrm{H} \times \mathrm{T} \times \mathrm{L}$ \\
\hline $\mathrm{H} \times \mathrm{L}$ & 2 & 0.1331 & - & - & $0.0030^{c}$ & 0.3 & $>0.6$ & $\mathrm{H} \times$ Site $(\mathrm{L})$ \\
\hline $\mathrm{H} \times \mathrm{T} \times \mathrm{L}$ & 2 & $0.1182^{\mathrm{a}}$ & 3.6 & $<0.05$ & 0.0054 & 0.4 & $>0.6$ & $\mathrm{H} \times \mathrm{T} \times$ Site $(\mathrm{L})$ \\
\hline $\mathrm{H} \times$ Site $(\mathrm{L})$ & 6 & 0.0094 & 0.4 & $>0.8$ & 0.0105 & 0.8 & $>0.6$ & $\mathrm{H} \times \mathrm{T} \times$ Site $(\mathrm{L})$ \\
\hline $\mathrm{H} \times \mathrm{T} \times$ Site $(\mathrm{L})$ & 6 & 0.0243 & 0.7 & $>0.6$ & 0.0134 & 2.1 & $>0.05$ & $\mathrm{H} \times$ Patch $(\mathrm{T} \times$ Site $(\mathrm{L}))$ \\
\hline $\mathrm{H} \times$ Patch $(\mathrm{T} \times$ Site $(\mathrm{L}))$ & 36 & 0.0345 & 2.1 & $<0.0003$ & 0.0063 & 1.4 & $>0.05$ & Residual \\
\hline Residual & $432^{b}$ & 0.0170 & 0.004 & & & & & \\
\hline $\begin{array}{l}\text { Cochran's C-test } \\
\text { Transformation }\end{array}$ & C & $\begin{array}{l}.072, p> \\
\text { None }\end{array}$ & 0.05 & & $\begin{array}{c}0.080, p< \\
\operatorname{Ln}(x+1)\end{array}$ & 0.05 & & \\
\hline \multicolumn{9}{|c|}{$\begin{array}{l}\text { a Pooled term: } \mathrm{H} \times \mathrm{T} \times \text { Site }(\mathrm{L})+\mathrm{H} \times \mathrm{Patch}(\mathrm{T} \times \text { Site }(\mathrm{L})) ; \mathrm{MS}=0.0331,42 \mathrm{df} \\
{ }^{\mathrm{b} D u e} \text { to missing data, there were } 413 \mathrm{df} \text { in the Residual for juveniles and } 396 \text { in the Residual for adults } \\
\text { "A denominator for these tests was provided after post-hoc elimination of other terms in the model that were not significant } \\
\text { at } \alpha=0.25 \text { (Winer et al. 1991) }\end{array}$} \\
\hline
\end{tabular}

low-shore habitats despite considerable spatial and temporal variation in patterns of abundance within each height. Successful recruitment was observed at different heights on the shore, when free space was provided. There were large differences in the density of recruits between the 2 locations considered. At Livorno, recruitment increased with height on the shore, but there was no clear pattern of significance in these effects. Few spat occurred in cleared plots at Punta Bianca, both in high-shore and low-shore habitats. Bare rock available for recruitment was greater high on the shore rather than lower down at all locations. There was no evidence for barnacles living higher up on the shore to grow at faster rates than those living lower down. The opposite pattern was observed for young barnacles in several cases. Mortality rates were generally larger in low-shore than highshore habitats for both young and adult barnacles. These results emphasize the importance of pre-emption of space and mortality of juveniles in generating patterns in the distribution and structure of populations of barnacles on rocky shores.

Despite a trend toward a larger number of recruits higher on the shore at Livorno, differences among heights were not large enough to fully explain the

Fig. 6. Chthamalus stellatus. Mean annual growth (+SE, $\mathrm{n}=$ 42 to 45 due to missing data) of juveniles in high-shore and low-shore habitats at 3 locations in 2 consecutive years
Juveniles
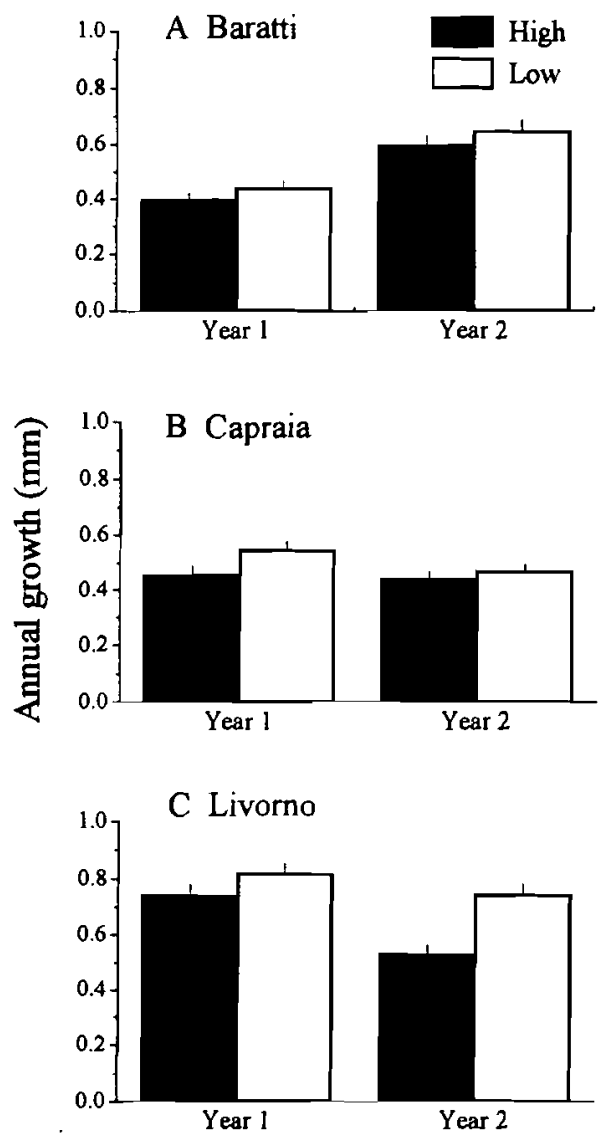
Table 6. Estimates of spatial and temporal variance in growth and mortality of barnacles

\begin{tabular}{|c|c|c|c|c|c|c|c|}
\hline $\begin{array}{l}\text { Response } \\
\text { variable }\end{array}$ & $\begin{array}{c}\text { Life } \\
\text { stage }\end{array}$ & $\begin{array}{l}\text { Height on } \\
\text { the shore }\end{array}$ & $\sigma_{\text {Plot }}^{2}$ & $\sigma_{\text {Patch }}^{2}$ & $\because \sigma^{2}$ Site & $\sigma_{\text {Location }}^{2}$ & $\sigma_{\text {Time }}^{2}$ \\
\hline \multirow[t]{4}{*}{ Growth } & Juvenile & High & 0.0153 & 0.0090 & 0.0008 & 0.0180 & 0.0000 \\
\hline & Juvenile & Low & 0.0172 & 0.0080 & 0.0000 & 0.0278 & 0.0000 \\
\hline & Adult & High & 0.0106 & 0.0002 & 0.0022 & 0.0470 & 0.0000 \\
\hline & Adult & Low & 0.0089 & 0.0010 & 0.0044 & 0.0476 & 0.0000 \\
\hline \multirow[t]{4}{*}{ Mortality } & Juvenile & High & 463.2000 & 11.0000 & 0.0000 & 18.8000 & 0.0000 \\
\hline & Juvenile & Low & 513.0000 & 119.3000 & 0.0000 & 174.5000 & 0.0000 \\
\hline & Adult & High & 216.9000 & 79.7000 & 31.2000 & 7.1000 & 0.0000 \\
\hline & Adult & Low & 406.4000 & 245.1000 & 45.0000 & 15.0000 & 0.0000 \\
\hline
\end{tabular}

Table 7. Chthamalus stellatus. ANOVA of mean mortality of juveniles and adults. Significant effects relevant to the interpretation of the results are indicated in bold

\begin{tabular}{|c|c|c|c|c|c|c|c|c|}
\hline \multirow[t]{2}{*}{ Source of variation } & \multirow[t]{2}{*}{ df } & \multicolumn{3}{|c|}{ Juveniles } & \multicolumn{3}{|c|}{ Adults } & \multirow[t]{2}{*}{ Denominator for $F$} \\
\hline & & MS & $F$ & $\mathrm{p}$ & MS & $F$ & $\mathrm{p}$ & \\
\hline $\mathrm{T}$ & 1 & 5219.6 & 0.8 & $>0.4$ & 2050.8 & 0.9 & $>0.4$ & $\mathrm{~T} \times \mathrm{L}$ \\
\hline $\mathrm{L}$ & 2 & 5851.2 & - & - & 7316.6 & - & - & No test \\
\hline Site (L) & 6 & 1750.9 & 4.8 & $<0.05$ & 1055.8 & 0.8 & $>0.5$ & $\mathrm{~T} \times$ Site $(\mathrm{L})$ \\
\hline $\mathrm{T} \times \mathrm{L}$ & 2 & 6731.4 & 18.6 & $<0.003$ & 2186.3 & 1.7 & $>0.2$ & $\mathrm{~T} \times$ Site $(\mathrm{L})$ \\
\hline $\mathrm{T} \times$ Site $(\mathrm{L})$ & 6 & 361.2 & 0.5 & $>0.8$ & 1308.7 & 0.9 & $>0.4$ & Patch $(\mathrm{T} \times$ Site $(\mathrm{L}))$ \\
\hline Patch $(T \times$ Site $(L))$ & 36 & 799.5 & 1.6 & $<0.05$ & 1406.8 & 4.5 & $<0.0001$ & Residual \\
\hline $\mathrm{H}$ & 1 & 73909.9 & - & - & 48460.2 & - & - & No test \\
\hline $\mathrm{H} \times \mathrm{T}$ & 1 & 2386.4 & 0.5 & $>0.5$ & 51.7 & 0.1 & $>0.9$ & $\mathrm{H} \times \mathrm{T} \times \mathrm{L}$ \\
\hline $\mathrm{H} \times \mathrm{L}$ & 2 & 2837.8 & - & - & 1585.8 & - & - & No test \\
\hline $\mathrm{H} \times \mathrm{T} \times \mathrm{L}$ & 2 & 4467.2 & 34.4 & $<0.0006$ & 3485.4 & 6.4 & $<0.05$ & $\mathrm{H} \times \mathrm{T} \times$ Site $(\mathrm{L})$ \\
\hline $\mathrm{H} \times$ Site $(\mathrm{L})$ & 6 & 254.4 & 2.0 & $>0.2$ & 3874.2 & 7.1 & $<0.05$ & $\mathrm{H} \times \mathrm{T} \times$ Site $(\mathrm{L})$ \\
\hline $\mathrm{H} \times \mathrm{T} \times$ Site $(\mathrm{L})$ & 6 & 129.8 & 0.2 & $>0.9$ & 545.4 & 0.7 & $>0.6$ & $\mathrm{H} \times$ Patch $(\mathrm{T} \times$ Site $(\mathrm{L}))$ \\
\hline $\mathrm{H} \times$ Patch $(\mathrm{T} \times$ Site $(\mathrm{L}))$ & 36 & 828.2 & 1.7 & $<0.01$ & 841.1 & 2.7 & $<0.0001$ & Residual \\
\hline Residual & $432^{\mathrm{a}}$ & 552.0 & & & 355.2 & & & \\
\hline $\begin{array}{l}\text { Cochran's } C \text {-test } \\
\text { Transformation }\end{array}$ & \multicolumn{3}{|c|}{$\begin{array}{c}C=0.047, \mathrm{p}>0.05 \\
\text { None }\end{array}$} & \multicolumn{3}{|c|}{$\begin{array}{c}C=0.054, p>0.05 \\
\text { None }\end{array}$} & & \\
\hline
\end{tabular}

observed differences in percentage cover. Thus, spatial variation in the delivery of larvae across the vertical gradient could explain only a small proportion of variation in the distribution of young and adult barnacles in this micro-tidal system. This contrasts to observations made in systems where tides are more important, where physical processes in the water column and local hydrodynamics near the substratum can generate spatial variation in density of larvae and then influence the distribution of adult animals (e.g. Grosberg 1982, Wethey 1986, Mullineaux \& Butman 1991). In contrast, actual recruitment to natural populations in the northwest Mediterranean probably reflected the variable effects of resident organisms at different heights on the shore (barnacles high on the shore and macroalgae lower down) on larvae of barnacles. Preemption of the substratum is a common process limiting settlement of larvae of these organisms (Denley \&
Underwood 1979, Gaines \& Roughgarden 1985, Chabot \& Bourget 1988). Previous experiments in the northwest Mediterranean have shown that the colonization of barnacles is enhanced by the presence of limpets, probably due to the indirect effects of these grazers that prevented the monopolization of the substratum by filamentous algae (Benedetti-Cecchi 2000).

Resident organisms do not necessarily prevent or limit recruitment of barnacles. In high-shore habitats, for example, the presence of ephemeral algae may increase the survival of recently settled larvae, as described by Minchinton \& Scheibling (1993) for the barnacle Semibalanus balanoides in Nova Scotia. Thus, organisms that have negative effects on barnacles in the more benign part of the habitat (low on the shore), may exert positive effects in stressful conditions (high on the shore) (Bertness 1989, Stephens \& Bertness 1991). In the case of barnacles, positive effects 


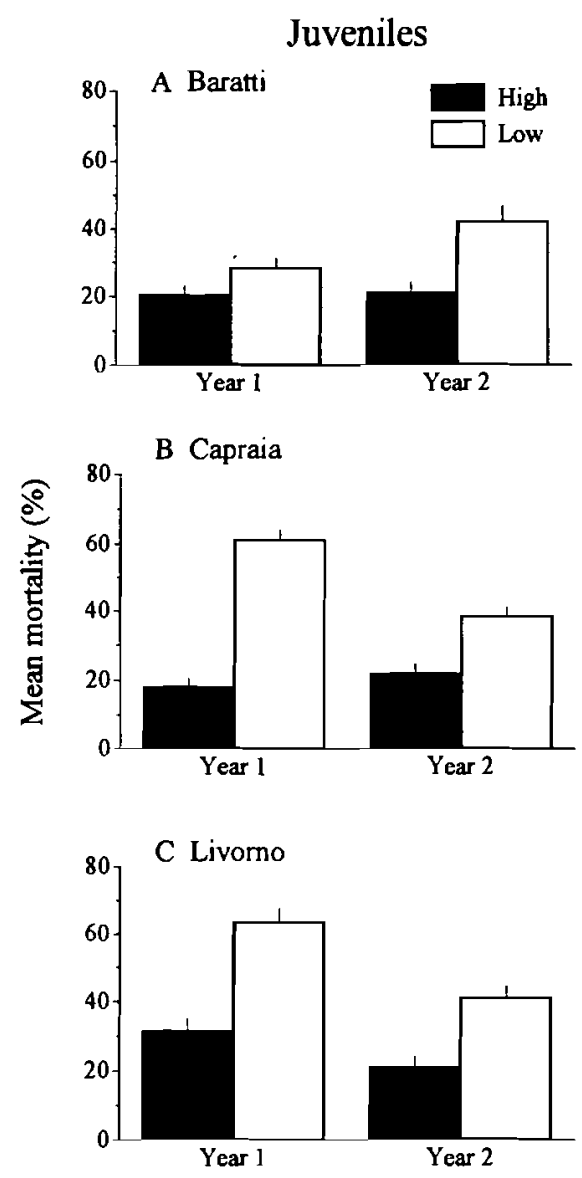

Fig. 7. Chthamalus stellatus. Mean annual mortality $(+\mathrm{SE}, \mathrm{n}=$ 37 to 45 due to missing data) of juveniles in high-shore and low-shore habitats at 3 locations in 2 consecutive years

may also result from chemical cues enhancing settlement of larvae close to adult individuals (Knight-Jones 1953, Crisp 1955, Wethey 1984, Chabot \& Bourget 1988, Raimondi 1988). These effects might explain the slightly larger number of recruits observed in plots high on the shore at Livorno, in comparison to quadrats occurring lower down. These plots, in fact, were cleared in a matrix of adult barnacles, while those in low-shore habitats were surrounded by macroalgae.

The results of this study indicate that high-shore habitats are not better than low-shore habitats in terms of processes influencing the growth of Chthamalus stellatus. Our analyses indicated that the annual increase in size of juvenile barnacles low on the shore was similar, and in some cases larger, than that of barnacles occurring in high-shore habitats. These results are similar to those found in other studies. For example, Bertness et al. (1991) documented faster growth of Semibalanus balanoides in low-shore areas. A number of processes could account for the differences between heights documented in this and our study. Growth is
Adults
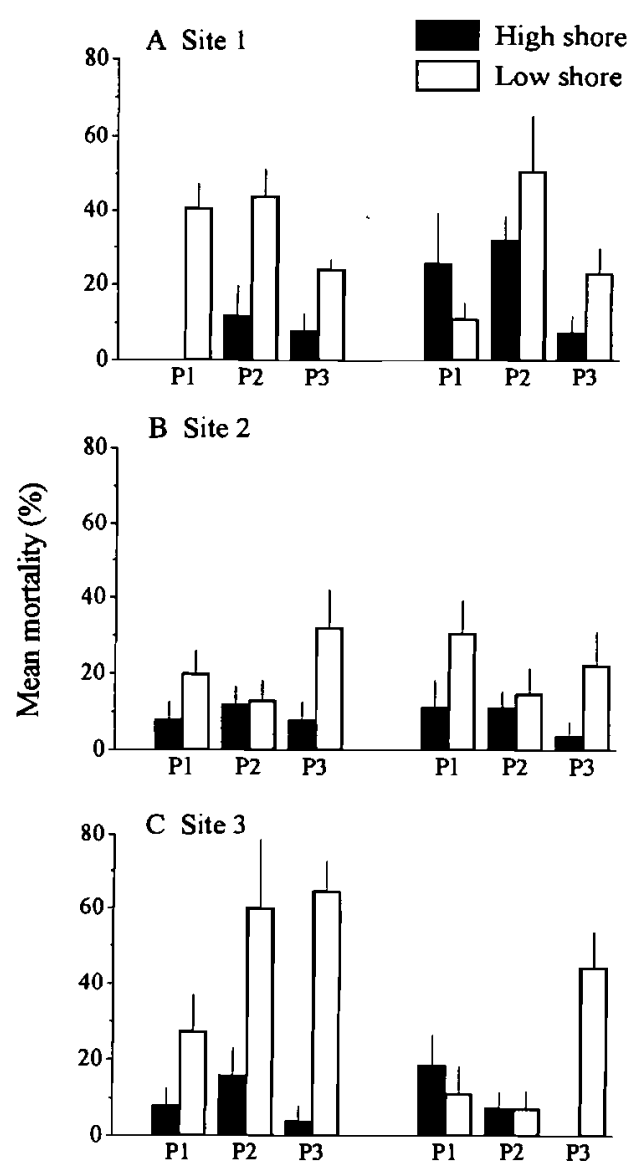

Fig. 8. Chthamalus stellatus. Mean annual mortality $(+\mathrm{SE}, \mathrm{n}=$ 5) of adults in high-shore and low-shore habitats. Data are from 3 patches nested within 3 sites at Livorno in Year 1

known to be positively related to the concentration of food in the water column and to the delivery of food by water currents (Bertness et al. 1991, Leonard et al. 1998). Thus, supply of food should be larger low on the shore where barnacles are nearly continuously submersed than in high-shore habitats where, at least in the Mediterranean, barnacles become submersed mainly during storms. This is because the distribution of barnacles high on the shore exceeds the mark of the high tide in the Mediterranean. In addition to the delivery of food, growth of barnacles in high-shore habitats could be limited by physical stress, although aggregation may reduce the effects of environmental harshness in these organisms (Bertness 1989). Aggregation, however, may result in elongated barnacles with small opercular or basal diameter (Barnes \& Powell 1950, Bertness 1989), so that density and growth may be negatively correlated across the vertical gradient (when size is expressed as opercular or basal diam- 
eter), providing an alternative explanation for the differences in patterns of growth between high-shore and low-shore barnacles documented in the present and other studies. These processes are likely to be of minor importance in comparison to other factors. In fact, differences in growth between high-shore and low-shore barnacles are still evident when comparing the growth of individuals maintained in isolation (Bertness et al. 1991).

In contrast to growth, processes affecting the mortality of Chthamalus stellatus in our study were more intense low on the shore. These processes maintained sparse, low-density populations relative to high-shore habitats. Studies on Semibalanus balanoides on rocky shores in Nova Scotia (Minchinton \& Scheibling 1993), have shown greater post-recruitment mortality in lowshore than high-shore intertidal habitats. Mortality of barnacles in low-shore environments is often a consequence of biological processes such as predation by whelks (Connell 1961b, Minchinton \& Scheibling 1993) and overgrowth by macroalgae, particularly encrusting algae (Denley \& Underwood 1979, Bertness et al. 1983, 1991, Bertness 1989). Whelks were uncommon on our shores, although they were locally abundant at some locations (e.g. at some sites in Capraia). Although we cannot discount predation as a processes influencing mortality of barnacles, it probably played a minor role in determining the observed patterns. In contrast, overgrowth by algae was a likely mechanism. In several cases we observed filamentous and encrusting algae over dead barnacles in low-shore habitats. Clearly, experiments are needed to determine whether barnacles are killed by algae or, alternatively, algae grow over barnacles once they are killed by other factors.

Our analysis on spatial variance at different scales emphasized the importance of both regional and local processes in regulating patterns of recruitment, growth and mortality of Chthamalus stellatus in the northwest Mediterranean. Oceanographic conditions influencing the delivery of larvae and food might account for greater recruitment and growth of barnacles at Livorno than at the other locations. The importance of these processes in generating large-scale variation in the demography and structure of populations of barnacles has been documented in other studies (Bertness et al. 1991, Sanford et al. 1994, Leonard et al. 1998). In contrast, intra- and inter-specific interactions and the effects of heterogeneity of the substratum are usually invoked as causal processes influencing patterns at small spatial scales (Connell 1961a,b, Chabot \& Bourget 1988, Lively et al. 1993). All these processes are potential candidates to explain the variability in recruitment, growth and mortality of barnacles observed in the present study, at scales of $10 \mathrm{~s}$ of $\mathrm{cm}$ (among plots) to a few metres (among patches). At these scales, however, hydrodynamic processes may also play a role (e.g. Eckman 1990).

Variation in recruitment, growth and mortality may have important ecological effects as these traits determine the local density of populations and ultimately affect the patterns of intra- and inter-specific interactions in assemblages. Several studies have explored the consequences of variable recruitment in the sea (e.g. Underwood \& Denley 1984, Roughgarden et al. 1987) and the implications of this variability for the population ecology of barnacles have been examined in detail (Grosberg 1982, Hawkins \& Hartnoll 1982, Caffey 1985, Gaines et al. 1985, Raimondi 1990, Pineda 1994, Ross \& Underwood 1997, Hyder et al. 1998). In contrast, less has been done on spatial and temporal variation in patterns of growth and mortality of these organisms (but see Bertness et al. 1991). Understanding variation in these traits is, however, important in order to make predictions about the effects of barnacles in assemblages. In particular, growth and final size strongly affect the capability of barnacles to compete for space with related taxa and with mobile animals such as limpets (e.g. Connell 1961a,b, Farrell 1991). In the northwest Mediterranean, dense populations of large barnacles can affect the establishment of foliose algae high on the shore (Benedetti-Cecchi et al. 1999); they can also reduce the local density of limpets in mid-shore habitats, indirectly facilitating the establishment of ephemeral algae late in succession (BenedettiCecchi 2000). Therefore, changes in density of barnacles can have both direct and indirect consequences in assemblages on our rocky coasts.

In conclusion, the results of this study emphasize the importance of free space, mortality and recruitment as factors affecting the structure of populations of barnacles in the northwest Mediterranean. Refinement of this space-mortality-recruitment model will require additional research on the processes causing mortality to low-shore individuals and on the causes of variability in these processes. More generally, our analysis indicates that future investigations on the population ecology of Chthamalus stellatus should address the causes of variation at the regional $(10 \mathrm{~s}$ to $100 \mathrm{~s}$ of $\mathrm{km})$ and local ( $\mathrm{cm}$ to $\mathrm{m}$ ) spatial scales.

Acknowledgements. We sincerely thank Prof. A. Myers for his help with the manuscript. The final version benefited from comments by Tony Underwood and 3 anonymous referees. This study was supported by the EU under the MAS3-CT950012 programme (Eurorock) and by a grant from the University of Pisa.

\section{LITERATURE CITED}

Barnes H, Powell HT (1950) The development, general morphology, and subsequent eliminination of barnacle popu- 
lations after a heavy initial settlement. J Anim Ecol 19: 175-179

Benedetti-Cecchi L (2000) Predicting direct and indirect interactions during succession in a midlittoral rocky shore assemblage. Ecol Monogr 70:45-72

Benedetti-Cecchi L, Airoldi L, Abbiati M, Cinelli F (1996) Estimating the abundance of benthic invertebrates: a comparison of procedures and variability between observers. Mar Ecol Prog Ser 138:93-101

Benedetti-Cecchi L, Menconi M, Cinelli F (1999) Preemption of the substratum and the maintenance of spatial pattern on a rocky shore in the northwest Mediterranean. Mar Ecol Prog Ser 181:13-23

Bertness MD (1989) Positive and negative density-dependent mortality and the population structure of Semibalanus balanoides in a sheltered bay habitat. Ecology 70:257-268

Bertness MD, Yund PO, Brown AF (1983) Snail grazing and the abundance of algal crusts on a sheltered New England rocky beach. J Exp Mar Biol Ecol 71:147-164

Bertness MD, Gaines SD, Bermudez D, Sanford E (1991) Extreme spatial variation in the growth and reproductive output of the acorn barnacle Semibalanus balanoides. Mar Ecol Prog Ser 75:91-100

Caffey HM (1985) Spatial and temporal variation in the settlement and recruitment of intertidal barnacles. Ecol Monogr 55:313-335

Carlile DW, Skalski JR, Batker JE, Thomas JM, Cullinan VI (1989) Determination of ecological scale. Landscape Ecol 2:203-213

Chabot R, Bourget E (1988) Influence of substratum heterogeneity and settled barnacle density on the settlement of cypris larvae. Mar Biol 97:45-56

Connell JH (1961a) The influence of interspecific competition and other factors on the distribution of the barnacle Chthamalus stellatus. Ecology 42:710-723

Connell JH (1961b) The effect of competition, predation by Thais lapillus and other factors on natural population of the barnacle Balanus balanoides. Ecol Monogr 31:61-104

Crisp DJ (1955) The behavior of barnacle cyprids in relation to water movement over a surface. J Exp Biol 32:569-590

Denley EJ, Underwood AJ (1979) Experiments on factors influencing settlement, survival, and growth of two species of barnacles in New South Wales. J Exp Mar Biol Ecol 36:269-293

Dethier MN, Graham ES, Cohen S, Tear LM (1993) Visual versus random-point percent cover estimations: 'objective' is not always better. Mar Ecol Prog Ser 96:93-100

Eckman JE (1990) A model of passive settlement by planktonic larvae onto bottoms of differing roughness. Mar Ecol Prog Ser 35:887-901

Farrell TM (1991) Models and mechanisms of succession: an example from a rocky intertidal community. Ecol Monogr 61:95-113

Gaines SD, Roughgarden J (1985) Larval settlement rate: a leading determinant of structure in an ecological community of the marine intertidal zone. Proc Natl Acad Sci USA 82:3707-3711

Gaines SD, Brown S, Roughgarden J (1985) Spatial variation in larval concentration as a cause of spatial variation in settlement for the barnacle, Balanus glandula. Oecologia $67: 267-272$

Grosberg RK (1982) Intertidal zonation of barnacles: the influence of planktonic zonation of larvae on vertical distribution of adults. Ecology 63:894-899

Hawkins SJ, Hartnoll RG (1982) Settlement patterns of Semibalanus balanoides (L.) in the Isle of Man (1977-1981) J Exp Mar Biol Ecol 62:271-283
Hyder K, Johnson MP, Hawkins SJ, Gurney WSC (1998) Barnacle demography: evidence for an existing model and spatial scales of variation. Mar Ecol Prog Ser 174:101-106

Knight-Jones EW (1953) Laboratory experiments on gregariousness during settling in Balanus balanoides and other barnacles. J Exp Biol 30:584-598

Leonard GH, Levine JM, Schmidt PR, Bertness MD (1998) Flow-driven variation in intertidal community structure in a Maine estuary. Ecology 79(4):1395-1411

Levin SA (1992) The problem of pattern and scale in ecology. Ecology 73:1943-1967

Lively CM, Raimondi PT, Delph LF (1993) Intertidal community structure: space-time interactions in the Northern Gulf of California. Ecology 74:162-173

Menconi M, Benedetti-Cecchi L, Cinelli F (1999) Spatial and temporal variability in the distribution of algae and invertebrates on rocky shores in the northwest Mediterranean. J Exp Mar Biol Ecol 233:1-23

Minchinton TE, Scheibling RE (1993) Free space availability and larval substratum selection as determmants of barnacle population structure in a developing rocky intertidal community. Mar Ecol Prog Ser 95:233-244

Mullineaux LS, Butman CA (1991) Initial contact, exploration and attachment of barnacle (Balanus amphitrite) cyprids settling in flow. Mar Biol 110:93-103

Pineda J (1994) Spatial and temporal patterns in barnacle settlement rate along a southern California rocky shore. Mar Ecol Prog Ser 107:125-138

Raimondi PT (1988) Settlement cues and determination of the vertical limit of an intertidal barnacle. Ecology 69:400-407

Raimondi PT (1990) Patterns, mechanisms, consequences of variability in settlement and recruitment of an intertidal barnacle. Ecol Monogr 60:283-309

Ross PM, Underwood AJ (1997) The distribution and abundance of barnacles in a mangrove forest. Aust $\mathrm{J}$ Ecol 22: $37-47$

Rossi RE, Mulla DJ, Jurnel AG, Franz EH (1992) Geostatistical tools for modeling and interpreting ecological spatial dependence. Ecol Monogr 62:277-314

Roughgarden J, Iwasa Y, Baxter C (1985) Demographic theory for an open marine population with space-limited recruitment. Ecology 66:54-67

Roughgarden J, Gaines SD, Pacala S (1987) Supply side ecology: the role of physical transport processes. In: Giller P, Gee $\mathrm{J}$ (eds) Organization of communities: past and present. Proc Br Ecol Soc Symp, Aberystwyth, Wales (April 1986). Blackwell Scientific Publications, London, p 459-489

Roughgarden J, Gaines SD, Possingham H (1988) Recruitment dynamics in complex life cycles. Science 241: $1460-1466$

Sanford E, Bermudez D, Bertness MD, Gaines SD (1994) Flow, food supply and acorn barnacle population dynamics. Mar Ecol Prog Ser 104:49-62

Schneider DC (1994) Quantitative ecology: spatial and temporal scaling. Academic Press, San Diego

Southward AJ (1987) Barnacle biology. AA Balkema, Rotterdam

Stephens EG, Bertness MD (1991) Mussel facilitation of barnacle survival in a sheltered bay habitat. J Exp Mar Biol Ecol 145:33-48

Stephenson TA, Stephenson A (1949) The universal feature of zonation between tide-marks on rocky coasts. J Ecol 37: 289-305

Thrush SF, Pridmore RD, Hewitt JE (1994) Impacts on softsediment macrofauna: the effects of spatial variation on temporal trends. Ecol Appl 4:31-41

Underwood AJ (1997) Experiments in ecology: their logical 
design and interpretation using analysis of variance. Cambridge University Press, Cambridge.

Underwood AJ, Chapman MJ (1996) Scales of spatial patterns of distribution of intertidal invertebrates. Oecologia 107: 212-224

Underwood AJ, Denley EJ (1984) Paradigms, explanations, and generalizations in models for the structure of intertidal communities on rocky shores. ln: Strong DR, Simberloff $D$, Abele LG, Thistle AB (eds) Ecological communi-

Editorial responsibility: Otto Kinne (Editor), Oldendorf/Luhe, Germany ties: conceptual issues and the evidence. Princeton University Press, Princeton, NJ, p 151-180

Wethey DS (1984) Spatial patterns in barnacle settlement: day to day changes during the settlement season. J Mar Biol Assoc UK 64:687-698

Wethey DS (1986) Ranking of settlement cues by barnacle larvae: influence of surface contour. Bull Mar Sci 39:393-400 Winer BJ, Brown DR, Michelis KM (1991)-Statistical principles in experimental design, 3rd edn. McGraw-Hill, New York

Submitted: September 6, 1999; Accepted: December 1, 1999 Proofs received from author(s): May 8, 2000 